\title{
Ambushing Basotho Customary Marriage
}

\author{
Louis Manyeli ${ }^{1}$ \\ ${ }^{1}$ Department of Philosophy, National University of Lesotho, Lesotho \\ Correspondence: Louis Manyeli, Department of Philosophy, National University of Lesotho, Lesotho. E-mail: \\ louismanyeli2@gmail.com
}

Received: May 17, 2019; Accepted: June 3, 2019; Published: June 17, 2019

\begin{abstract}
This paper describes and evaluates Basotho customary marriage as entailed in Sesotho law. It argues that lobola (dowry) and polygamy permitted by Sesotho law are detrimental to the dignity of women, and consequently ought to be obliterated. It also argues that under customary marriage the re-marriage of widows is a barricade caused by the customary practice of the bohali (the dowry). It further argues that the long standing practice of the bohali in customary marriage perspicuously does injustice to the family of the bridegroom. Regarding polygamy allowed by customary marriage under Sesotho law it is argued that this explicitly amounts to the dehumanization of women. Ideally the paper is an attempt to rescue women from the long standing suppression by men Lesotho in as far as Basotho customary marriage is concerned.
\end{abstract}

Keywords: bohali (lobola), customary marriage, Sesotho law, dual marriages, polygamy

\section{Introduction}

The problem of women subordination to men in Basotho on-going customary marriage is of utmost importance because suppression of women by men in customary marriage is detrimental to the dignity of women, and it ought to be seriously addressed and obliterated. Unfortunately, this problem has never been addressed. The literature found on Basotho customary marriage, most of which was written by the first Missionaries, only describes the actual situation and not a genuine evaluation of this deplorable customary marriage.

This problem deserves a new research that attempts to rescue women from the unwanted conditions they encounter in customary marriage. Prior to the attempt of this paper to endeavour solving this problem no one dared to explore the importance of this problem. First, most probably because the victims are voiceless in this country and are regarding their subordination as part of their culture, women never attempted to explore the importance of the problem. Second, it is most probable because the oppressors enjoy their status. That is why the minimum literature available on this very important topic is not at a critique but rather a mere description of Basotho customary marriage.

Russell doubts those who question whether it is the business of philosophers to indulge in customs. In our case here Basotho customary marriage is such a custom likely to be doubted. According to Russell, the person who doubts the impact of philosophy is as a matter of fact confined to the knowledge acquired from simple common sense. Such a person is said to be naive of the philosopher's mind, the mind that deploys deliberate reason in attempting to solve serious problems in life, in our case, studying gender equality advocacies. Russell acknowledges that certainty of philosophy actually consists in its very uncertainty. A question that cannot be answered definitely forms the residue we call philosophy. This is why the value of philosophy consists to a great extent in its very uncertainty (Russell, 1998, p. 1132). It is in this mode of thought that the present author attempts to suggest justifiable possibilities which will most probably enlarge our thoughts and free many people from the tyranny of Basotho customary marriage.

I concur with Russell's mode of thought that "While diminishing our feeling of certainty as to what things are, it [philosophy] greatly increases our knowledge as to what they may be; it removes the somewhat arrogant dogmatism of those who have never travelled into the region of liberating doubt, and it keeps alive the sense of wonder by showing familiar things in our unfamiliar light" (Russell, 1998, p. 1133). The author of this paper, who incidentally by profession is a philosopher, intends to remove the arrogant dogmatism of those who have never attempted to travel into the region of liberating doubt in as far as Basotho customary custom is concerned. 
In my article "Rejuvenating the Ancient Basotho Rite of Initiation", I have shown some tyrannies of Basotho customary initiation and proposed a far much preferable solution to be implemented. Similarly, in the present paper I show some tyrannies of Basotho customary marriage and propose a better solution to be implemented.

Omoregbe holds the view that "the essence of philosophy is not argument but reflection, and this does not have to take the form of the Western-type argument. Wherever there reflection on the fundamental questions about man or about the universe... there is Philosophy (Omoregbe, 2005, p. 8).

I consummately concur with Omoregbe's view point that the essence of philosophy is reflection and his other contention that it is wrong to confine philosophy to Western-type philosophy that is primarily focussed on argumentation. He correctly maintains that 'philosophy is essentially a reflective activity'. Furthermore, it is in this sense that the assumption once announced by the founder of moral philosophy, Socrates (who lived around 470-399 B.C.) that the unexamined life is not worth living and that while hard thinking about issues disturbs, it also consoles, is still germane today. Inspired by such sagacious men of great learning and thinking I deem it most appropriate to reflect on the custom of marriage amongst the Basotho with the sole intention of attempting to perfect it.

It is worth noting that current literature on the topic at stake is lacking. This is indicative of the fact that until to date no Scholar in Lesotho has either set down to write a paper appraising or challenging the customary practices of the bohali and polygamy. It is worth noting that the present author is the first to reflect on customary practices and dehumanization of women in Lesotho, in as far as Basotho customary marriage is concerned. This is wy the only literature on Basotho customary marriage is written mainly by the first Missionaries, and as such it is purely historical and descriptive. A question may correctly be asked: If women in Lesotho are discontent with these practices, why are they silent? I presume that perhaps if one has been suppressed and oppressed for too long, one ends up not being aware of the suppression and oppression. So, a good Samaritan (a man) must come from outside to their rescue.

\section{The Nature of Customary Marriage}

In the West marriage is a formal agreement between two adults who enter into a life-time partnership. This lifetime contract is made before a marriage officer, either an ecclesiastical minister or a magistrate. There are two conditions worth mentioning in as far as civil and ecclesiastical marriages are concerned: First, the condition of having civil and ecclesiastical marriages is such that the parties concerned should have reached at least the age of eighteen. Second, both civil and ecclesiastical marriages require that there be a mutual consent between the two parties intending to enter into a marriage. Even in the case of a family raising words of demurral to the marriage, as long as he parties have reached the age of eighteen and have duly consented to the marriage, such a marriage is regarded as being legitimate and legal before the law. In this case a marriage certificate, that is, a copy of the record of a legal marriage may be issued by the marriage officer. In both civil and ecclesiastical marriages the reckoning of the bohali is not required to vindicate the validity of the marriage. Polygamy in both civil and ecclesiastical marriages is strictly forbidden. "So far as the husband's legal capacity to marry a second wife polygamously is concerned, the clear answer is that he cannot do so" (Poulter, 1981, p. 40). Civil law allows the husband to marry the second wife while the first is still alive only if the civil court has granted a divorce.

Incongruously, in Lesotho "A customary marriage... is 'deemed' to be completed when there is agreement between the parties to the marriage coupled with parental agreement both as to the marriage and as to the amount of the bohali, and when part, at least, of the bohali has actually been paid" (Poulter, 1981, p. 61). Initially, customary marriage was a formal agreement between the two families without the consent of the bride and bridegroom. Later, with the influence of the church, the parties had to consent to the marriage. This agreement between the two families was sealed with the family of the bridegroom paying the bohali either in the form of cattle or money. The problem arises in the case whereby there is no parental agreement; in that case there is no marriage customarily.

The inclusion of parental agreement is frequently perplexing when the families object to the decision of the parties to enter into a marriage. Parents in customary marriage interfere with the choice made by the parties to the extent that one of the parties at times marries a partner chosen by the parents. In the case whereby a man is compelled by his parents to marry a woman of their choice he is directly or indirectly moved towards the direction of polygamy. Sesotho customary law does allow a man to procure a second wife; and this time the husband does not need the permission and approval of his family. He now is entitled by customary law to marry freely a woman of his own choice. Consequently, the first wife faces the worst scenario since she becomes an object that may be visited by the husband once in a while. Unfortunately, while the husband is free to procure a second wife, the wife is never free and allowed to procure a second husband. 


\section{The Bohali}

Sesotho customary marriage is such that it is fundamentally an agreement between the two families of the bride and the bridegroom. Poulter correctly maintains that "The negotiations for the marriage are conducted through the traditional channels and family representatives settle how much bohali should be paid" (Poulter, 1981, p. 35). It is of paramount importance to stress the fact that Sesotho customary marriage is essentially and primarily an agreement between the two familiies. The bohali is just a seal signifying that an agreement has been made. This why the amount of money or cattle or money to be paid is secondary, the agreement is primary that there be a marriage customarily.

The first Missionaries vigorously attempted in vain to quash the paying of the dowry in Lesotho. They were convinced that "This custom reduces the woman to a state bordering on slavery" (Casalis, 1997, p. 182). Indistinguishably, Ellenberger maintains that "this custom degrades the woman, and places her in the position of a slave, and it is true that it is liable to abuse, and opens the door to cupidity" (Ellenberger, 1997, pp. 272-273). They regarded the bohali as a purchase turning a woman into a commodity, and as such an object that could easily be used as a slave. This is why the first Missionaries, namely, the Paris Evangelical Missionaries Society refused to countenance customary marriages and so accordingly expelled from the church membership forthwith anyone paying or receiving the bohali.

But the same Ellenberger commits the fallacy of inconsistency when he holds that: "To show that this system does not necessarily degrades the woman to the position of a slave or a chattel, one needs only point to the many famous women of ancient more recent times, such as Mantatise, queen of the Batlokoa, and many others who did not rule, who were all of them married according to it [i.e. Sesotho customary law allowing the bohali]. The respect and obedience paid to them would hardly have been rendered to slaves or chattels" (Ellenberger, 1997, p. 274). After more than a hundred years, as late as 1954, it was only then that the Paris Evangelical Missionaries Society ruled out banning the bohali payments. What had been going on behind the scenes for upward of a hundred years was only then officially countenanced.

Perspicously, this contradiction verifies that the poor Missionaries misapprehended the Sesotho customary marriage. Casalis, one of the first Missionaries provides the real reason why they resisted the Sesotho customary marriage that permitted and encouraged bohali says: "This arrangement, so contrary to our customs and to the spirit of the Gospel, appears quite natural to the African tribes" (Casalis, 1997, p. 185). Evidently the Missionaries were antagonistic to this arrangement, not because it was immoral in itself, but simply because they misconstrued it as it was antipathetic to their own arrangement in France where they came from. It was in this way that any practice alien to their own culture was classified as pagan and therefore contrary to the Gospel. But today the same church brought by the same Missionaries approve and regard the bohali as passable, no longer contrary to the same Gospel they preached.

Today the dominant churches in Lesotho, influenced by inculturation accept the once vehemently rejected Sesotho customary marriage with its inclusion of the bohali. The bohali is no longer conceived as being contrary to the Gospe. These dominant churches admit that their pioneers misconstrued Sesotho customary marriage avowing that it places the woman in the position of slaves. However, I am antipathetic to this custom, more especially to its main element, namely, the bohali. I argue for its abolition neither because it 'reduces the woman to a state bordering on slavery' nor since it is contrary 'to the spirit of the Gospel' as the first Missionaries proclaimed, but rather for the reasons I lay out below.

In my view, the bohali violates the women's fundamental human right to their freedom of choice. According to Sesotho customary law, once the bohali has been paid, either in the form of money or cattle as agreed by the two families, the woman ipso facto becomes part of the family of the bridegroom. Casalis correctly maintains that "The death of the husband does not liberate the wife. She falls by law to one of the brothers or to the nearest relation of the deceased" (Casalis, 1997, p. 190). The woman is no longer free to marry a man of her own choice since the lobola has tied and incorporated her to the family of her deceased husband. Sesotho customary law entitles the younger brothers of the deceased to marry her. However, "There are, nevertheless, some generous families who do not assert this right, but allow the widow to marry again as she pleases" (Casalis, 1997, p.190). It is important to note that she has no right to re-marry, they are just doing her a favour to which they are not morally obliged to make. In this way the bohali deprives the woman of her right to choose another man after the demise of her husband. She now depends entirely on the generosity and mercy of her deceased husband's family

I partly agree with Casalis that "the fact that the widoe is compelled to remain in the family, although she has already born children to the deceased, proves that the purchase of which she was the object is the chief obstacle to her liberation" (Casalis, 1997, p. 190). I disagree with Casalis that the bohali is the selling of the bride to the family 
of the bridegroom since there can still be marriage according to customary law without the bohali from the bridegroom's family. The bohali is, as I have shown earlier a seal that the agreement between the two families has been reached. Sesotho customary marriage is not concerned about buying of the bride by the family of the bridegroom or the bride's family selling of their daughter, it is an agreement made by the two families.

On the other hand, I concur with Casalis that the bohali becomes an impediment for the woman to remarry a man of her own choice when her husband ceases to exist. This claim is attested by the fact that in the case whereby there was no bohali paid there is no hurdle hindering the widow to choose her new spouse. Poulter also confirms that "It may well be that a widow whose first marriage was a customary one can only remarry customarily if she first obtains a divorce from her deceased husband's family and if the bohali is restored to them" (Poulter, 1981, pp. 46-47). If the marriage is a customary one, the woman is not only tied to her husband, but also to the husband's family. So, if the husband dies, she is still considered as part of his family. What makes it most difficult for her to alienate herself from her late husband's family is the bohali that in most cases if not all is hard to restore. I, therefore, conceive the best and only solution to liberate the woman as the complete abolition of the bohali.

It is discriminatory and disreputable that an equal partner in marriage, simply because is now a widow whose marriage was sealed by a given number of cattle or a certain amount of money, must now depend entirely on the generosity and compassion of another family to gain her liberation. The discrimination and unscrupulousness consist in that while customary law proscribe the widow to marry as she pleases, it authorizes and even invigorates the husband to marry as he pleases. If the barricade for the poor defenceless widow's liberation is the dowry, fairness requires that the bohali be obliterated.

Matsela, Z. A. (1990, p. 28) on customary marriage specifies that traditionally customary marriage was essentially an agreement between the two families. As indicated earlier, lobola came into existence signifying that an agreement has been reached between the two families. That is why there was no fixed amount of cattle or money required for the bohali. The amount varied with the times, and, according to Mr. Abousset, "at one time two or three head was enough. Today it stands at fifteen to twenty head" (Ellenberger, 1992, p. 272). Chiefs and wealthy families agreed on larger amount of money or many cattle.

The main problem with the dowry is that it ultimately ties the woman to her husband's family and she becomes a property of that family. Ellenberger correctly maintains that "A woman ostensibly and in fact does marry her husband, but theoretically she belongs, not to him alone, but to his family, who indeed have generally contributed to her dowry" (Ellenberger, 1992, p. 274). Given the fact that lobola makes a woman part of her husband's family, and given that even after her husband's demise she is still tied to that family, clearly then the bohali turns out to be detrimental to one of her fundamental rights, namely, her basic right of freedom of choice.

According to Casalis, "The fact that the widow is compelled to remain in the family, although she has already born children to the deceased, proves that the purchase of which she was the object is the chief obstacle to her liberation" (Casalis, 1997, p. 190). The dowry, which initially was just a symbol of agreement now turns out to be a barrier to the liberation the woman is rightfully entitled to. In his celebrated Legal Dualism in Lesotho professor Poulter writes: "It may well be that a widow whose first marriage was a customary one can only remarry customarily if she first obtains a divorce from her deceased husband's family and if the bohali is restored to them" (Poulter, 1981, 46-47). Almost in most cases the restoration of the bohali is unfeasible, and the innuendo is that the widow's tie to her late husband's family is unbreakable. Evidently, the widow's liberation depends to the exclusion of everything also on the quashing of the bohali.

Generally, male domination in Lesotho customary marriages is still prevalent, and this has led women to have inferiority complex in their relationships. The husband does not regard his wife as an equal partner. Casalis correctly says that 'The Mosuto, in speaking of himself and his family, invariably says, 'I and my children;' and it is understood that the wife is reckoned among the latter" (Casalis, 1997, p. 182). In my view, one of the main factors contributing to the prevailing and persisting male domination in Sesotho customary marriages is the current practice of lobola. It gives the bridegroom the feeling of possessing the bride in the same manner that he possesses his children. I restate my claim, therefore, that lobola ought to be abolished.

I conclude this section reflecting upon whether it is fair at all for the bridegroom's family to pay the bohali. Is a right to dowry a justified claim by the family of the bride on the family of the bridegroom? Can the family of the bride on its claim to dowry provide sufficient reasons why the bridegroom's family ought to respect such a claim?

A brief background of the bohali may suffice to respond to the above mentioned questions. Matsela (1990, pp. 2728) mentions that the amount of cattle determining the bohali varied. Normally at a certain given time the bohali was complete when the bridegroom's family gave twenty cattle. But for the princesses the bohali amounted to thirty to forty cattle. 
Matsela makes an important observation that since the bohali was essentially an agreement between the two families, sometimes even two cattle sufficed to complete the bohali. It is in this way that there is a sying that: 'monyala - ka - peli o nyala oa hae'; that is to say, even with the little one has the bohali may be considered complete. About marriage, Ellenberger has this to say: "Marriage was effected by payment to the bride's family of a consideration in cattle, called bohali (dowry). The amount varied with the times, and, according to Mr. Arbousset, at one time two or three head was enough. Today it stands at fifteen to twenty head" (Ellenberger, 1997, p. 272).

The financial situation of ancient antiquity in Lesotho, where families could with ease afford to give twenty to forty cattle for the bohali is far from being commensurate with the current unpalatable financial conditions. Given the scarcity of cattle today, and given how poverty-stricken our nation is, I find no sufficient reason to compel the bridegroom's family to comply with the costly demands of the bohali.

Besides, both families had equal binding parental responsibilities in the upbringing of their children. I do not see why one family should at one stage feel having a moral obligation to claim the right to dowry from another family. Given the exorbitant value of education, it is disproportionate that at the end of their respective expensive training one family should feel duty-bound to comply with the demands of the bohali from another.

In my view, the principle of justice or at least fairness is such that it is discriminatory for the bride's family to clamour for dowry from a family that has equally sacrificed itself educating its own son. Fairness requires that instead of the bride's family clamouring for dowry, both families ought to join hands and furnish their newly married children with necessary requirements for the new family.

\section{Polygamy}

Polygamy is a practice of having more than one wife or husband at the same time. In Lesotho polygamy is a custom whereby a man has more than one wife at the same time. A polygamous man is not restricted to a certain fixed number of wives he wants to marry; he is allowed to marry as many as he can afford. A typical example is that of the founder of the nation, Moshoeshoe I, in his old age he did not know the of his wives because they were too many. Confined to Lesotho customary marriage the definition of polygamy already denotes how gender biased this custom is. While allowing a man to have more than one wife, it forbids a woman to have more than one husband.

One may out of curiosity and correctly ask a question: how did polygamy become so prevalent among the Basotho? Here I am writing about a custom that is legal by Sesotho customary law until today. History attests that Moholmi, the chief advisor and mentor of Moshoeshoe I, who in turn was the founder of the Basotho Nation, recommended that Moshoeshoe I should marry girls from neigbouring clans.

The rationale behind the recommendation for polygamy was to ensure that Lesotho was likely to have a lasting peace with its neighbouring countries. Ellenberger attests that "Mohlomi by his system of forming family ties with other tribes far and near, set the example of an unlimited polygamy. In fact, there is no limits except his means, to the number of wives a man may have" (Ellenberger, 1997, p. 279). The advice of chief Mohlomi to king Moshoeshoe I makes sense and really worked for Moshoeshoe I. Understandably one cannot attack his son-in-law without directly attacking his own daughter and one's grand- children. However, it is worth noting that this motivating factor for polygamy uses women as mere shields, that is, as mere objects for maintaining and retaining peace. This custom emerged from the chiefs and the rich men took advantage of their wealth because they could afford to pay lobola.

Casalis mentions another motivating factor for polygamy: "the more wives a man possesses, the more lands he has at his disposal, and the more he may hope to see the number of these hands increase" (Casalis, 1997, p. 188). It must be noted that land in Moshoeshoe I days was in abundance, all that was required was manpower to till it. The chiefs and wealthy men who could afford to occupy land in abundance used their wives and children as free labour to till their grounds, draw water, provide fuel and the like for free. It is no uncommon occurrence that the custom of polygamy was and is still practiced mainly by the wealthy in Lesotho. They marry many wives to further increase their wealth. Incontrovertibly, here is another instance whereby women are used as mere instruments to meet the needs of men. This, undoubtedly amounts to violating the dignity of women and therefore perspicuously dehumanising them relegating them to the sphere of animals.

However, I further altercate the Missionaries' repeated saying that "the chiefs who have visitors in abundance, and who owe hospitality to everyone, have so many wives, and display them as a proof of their opulence" (Casalis, 1997: 188). Rachels reminds us the Eskimo custom turned out to be very different from our own. He says the men often had more than one wife, and they would share their wives with guests, lending them for the night as a sign 
of hospitality (Rachels, 1986, p. 13). The practice of offering wives to visitors and friends was prevalent in Eskimo of ancient antiquity, not amongst the Basotho. The two reasons for polygamy mentioned above are the only ones accounting for polygamy in Lesotho. A married Mosotho man, even if incidentally happens to be a polygamist, cannot afford to offer any of his wives to other men. This is why we have ample examples of polygamists who either castrated or mercilessly murdered men caught having sex with their wives.

Taking the chiefs' families as our model, Ellenberger, for the purposes of description, divides marriages by the same husband into three main categories:

First, "the great wife, the wife given to a man by his father. She stands alone among her fellows, and her position and dignity are unassailable" (Ellenberger, 1997, p. 279). In Lesotho's ancient antiquity, the first wife, usually referred to as the great wife, was chosen by the family without the consent of the spouses. Fortunately, this unwanted element no longer exists, the choice is now made by the bride and the bridegroom. The two families simply assist in the arrangement of the marriage as discussed earlier. I regard this first category of marriage, where the future spouses make a choice themselves as the only genuine marriage abiding by the principle of justice whereby they are treated as adults whose dignity is duly respected.

Second, "important wives married by the husband himself. These are women of position, and become the mothers of important men. They and their children take rank in accordance with the dates of their marriages" (Ellenberger, 1997, p. 279). The second wife, third, and so on, are chosen by the husband himself, without reference to his parents. This time his parents have no moral obligation to actively participate in the dowry. It is in this category where only wealthy men feature marrying as many wives as they desire and Sesotho customary law permits this practice.

In this second category there are two points worth noting: firstly, even if wives in this category are classified as important wives, the fact still remains that they are subject to the domination and oppression of their husband. Polygamy clearly relegates women to the secondary position. Secondly, this category is gender biased because it does not accord 'important husbands' to be married by the wife herself. Only men are privileged to marry wives and not vice versa.

Third, "The ngoetsi - these are married as servants, and as such attached to the houses of the more important wives... She is lent to visitors, and forms intimacies of her own, as often as not with her husband's growing sons" (Ellenberger, 1997, p. 279). Ellenberger further maintains that the husband once in a while has sex with them, and that all their children born of them bear his name. there are three points worth noting here:

Firstly, this category of servants being married by the husband in view of serving important wives is not known both in traditional and modern Sesotho customary marriage. If a husband marries a wife primarily to enslave her to another wife, clearly this implies marrying her as a slave of another, particularly given the fact that these ngoetsi's worked for the important wives without being paid. Slavery of this type never existed in Lesotho.

Secondly, the lending of wives by the husband to his visitors never existed in Sesotho customary marriage. I have already shown emphatically that this allegation is unfounded. I presume that the Missionaries assumed that given the increasing number of wives, and given the social character the Basotho had, it was possible to assume that wives were offered to friends by the husband.

But this presumed assumption had no basis. Fidelity in both monogamous and polygamous marriages were considered as ideal. At times infidelity occurred in both monogamous and polygamous marriages, but this was regarded as being immoral. Ellenberger presents his view as if only wives cheated; the polygamous husband also cheated on his many wives. Regardless who cheated, infidelity was condemnable and regarded as being immoral.

Another misapprehension of the Missionaries was their conception of the Basotho as being amoral in sexual matters. The Basotho recommended and regarded sexual intercourse as being moral only in marriage either monogamous marriage or polygamous marriage. Cheating in as far as monogamous or polygamous marriages and pre-marital sex were concerned were always castigated as being immoral. Clearly, it is inconceivable that the Basotho could be amoral in sexuality while being so strict on behaviour in sexual intercourse.

Thirdly, to hold the view that these wives formed intimacies of their own with their husband's growing sons imply that incest was accommodated in polygamous marriages. In Sesotho the wife of one's father's younger wife is his mother. It is a taboo that is abhorred to have sexual intercourse with one's mother either a biological or one's younger wife. In fact, incest was and is still considered as a crime given a severe punishment.

All in all, I consider polygamy as being morally condemnable because it regards women as objects of men. First, marrying a woman primarily to form a tie with neighbouring clans clearly demonstrates that she is merely being used as an object for maintaining peace with other tribes. Second, to marry a woman in view of having more hands 
at one's disposal is also using her as a mere tool. According to me, as used in these two senses the woman's dignity as a person is violated. To use Kantian terminology the woman in polygamy is not used as an end-in-itself as it should be the case, but rather she is being used as a means to an end. Evidently, a woman should not be used as a mere tool since this amounts to dehumanizing her.

\section{Conclusion}

All in all, credit must be given to the first Missionaries, particularly, to Eugene Casalis, for having put down in writing the tradition and customs of the Basotho. However, I demonstrated against some misinterpretations they have made in as far as Sesotho customary marriage is concerned. I have attempted to show that they misconstrued Sesotho customary marriage because they compared it with their own customary marriage in France and thus found Sesotho customary marriage pagan and immoral since it was alien to their own. In as far as Sesotho customary marriage is concerned I have made a case against the bohali and polygamy.

The Laws of Lerotholi stipulates that "A marriage by Basuto custom in Basutoland shall be deemed to be completed when:

(a) There is agreement between the parties to the marriage;

(b) There is agreement between the parents of the parties or between those who stand in loco parentis to the parties as to the marriage and as to the amount of the bohali;

(c) There is payment of part or all of the bohali... (The Laws of Lerotholi, p. 29).

First, I have attempted to show that the only plausible and acceptable condition for the completion of marriage is that there should be an agreement between the parties to the marriage. This in in line with respecting their dignity as adult as adult human persons who ought to be trusted to make decisions for themselves freely.

Second, the second condition of the families' involvement in the agreement ought to be ruled out since marriage is going to be lived by the parties concerned alone. However, in this regard I have shown that from a cultural point of view, the families may be continue to be involved later in the arrangement of the feast and assisting of the parties, especially as difficulties arise later in life. The advantageousness of the social aspect of Sesotho culture is that as time goes on the couple may need the support of the family, especially in gruelling moments in marriage.

Third, I have ruled out the third condition of the bohali. Firstly, I have shown that this element of the bohali is to a great extent a contributing factor to the long-standing and persisting male domination and suppression of women in Sesotho customary marriage. Secondly, I have attempted to demonstrate that the bohali does injustice to the family of the bridegroom that has equally contributed in the expensive upbringing of their son. I have therefore suggested that the bohali be replaced by the two families contributing to finance the newly formed family to kick start.

Lastly, I have argued for the extermination of polygamy still permitted by Sesotho customary law. I discussed the two motivating factors for polygamy: ensuring that the polygamous chief has a lasting peace with neighbours whose daughters he has married and ensuring that the polygamous man has more lands at his disposal and that he increases manpower for free. I have attempted to that in both cases women are perspicuously being dehumanized because they are merely being used as means to further men's ends rather than being used as ends-in-themselves.

\section{References}

Casalis, E. (1997). The Bassutos. Morija: Morija Museum \& Archives.

Ellenberger, F. (1997). History of the Basuto: Ancient and Modern. Morija: Morija Princing Works.

Gill, S. (1993). A Short History of Lesotho. Morija: Morija Printing Works.

Laws of Lerotholi. (1959). Morija: Morija Sesuto Book Depot.

Matsela, Z. A. (1990). Bochaba ba Basotho. Mazenod: Mazenod Publishers.

Omoregbe, J. (2005). Knowing Philosophy: A General Introduction, $2^{\text {nd }}$ Ed. Lagos: Joja Press Limited.

Poulter, S. (1987). Legal Dualism in Lesotho. Morija: Morija Sesuto Book Depot.

Russell, B. (1998). "The Problems of Philosophy". In Louis Pojman (ed.). Classics of Philosophy, vol. II. Oxford: Oxford University Press. 


\section{Copyrights}

Copyright for this article is retained by the author(s), with first publication rights granted to the journal.

This is an open-access article distributed under the terms and conditions of the Creative Commons Attribution license (http://creativecommons.org/licenses/by/4.0/). 